Article

\title{
Strategy for the Sustainability of a Food Production System for the Prosperity of Low-Income Populations in an Emerging Country: Twenty Years of Experience of the Peruvian Poultry Association
}

\author{
Alejandro Fontana ${ }^{1, * \mathbb{C}}$, Ignacio de los Ríos Carmenado ${ }^{2} \mathbb{D}$, Johan Villanueva-Penedo ${ }^{1}$, \\ José Ulloa-Salazar ${ }^{1}$ and Denisse Santander-Peralta ${ }^{1}$ \\ 1 PAD Escuela de Dirección, Universidad de Piura, Av. Aldebarán 160, Lima 15023, Peru; \\ j.villanueva.penedo@gmail.com (J.V.-P.); jose.ulloa.salazar@gmail.com (J.U.-S.); \\ dsantander@mba.pad.edu (D.S.-P.) \\ 2 GESPLAN Research Group. School of Agricultural, Food and Biosystems Engineering, Universidad \\ Politécnica de Madrid, Calle Ramiro de Maeztu, 7, 28040 Madrid, Spain; ignacio.delosrios@upm.es \\ * Correspondence: afontana@pad.edu; Tel.: +51-999-166-073
}

Received: 29 September 2018; Accepted: 30 October 2018; Published: 3 November 2018

\begin{abstract}
This research shows a business initiative that has been able to integrate into an environmentally sustainable food production system, such as poultry farming, a positive impact on food security and public health patterns of low-income populations in an emerging country. For a process that took 20 years, the adopted strategy has become a positive experience of sustainability and prosperity in low-income populations in Peru. The objective of the research is to conceptualize and identify the key elements of this experience so that its replication in other food production systems to impact favorably the prosperity of such vulnerable population. The Working With People (WWP) model, a validated methodology for analyzing the sustainability and prosperity of rural areas in Europe, is used for the analysis of this experience. The analysis shows that the presence of the three dimensions of this model (political-contextual, technical-business, and ethical-social) ensure the sustainability of a food production system that has an impact on the prosperity of low-income populations in emerging countries. This balance is important to enrich the connections between sustainability and prosperity, with other concepts such as core values in companies, public-private cooperation, food safety, inclusion and consumption patterns.
\end{abstract}

Keywords: sustainability; food systems; nutrition; public-private cooperation; corporate values; sanitary control; food safety; prosperity

\section{Introduction}

The case study shows a private initiative that has integrated the perspective of an environmentally friendly food production, such as poultry farming [1], into a positive impact on consumption and social inclusion, and a contribution to public health standards.

The Peruvian Poultry Association, founded in 1938, is a group of companies dedicated to raising poultry products, and which brings together the whole domain of companies in the sector. Currently, the eleven most important companies represent $85 \%$ of market share. On the initiative of the board of directors of this association, a system of poultry meat production has been developed in Peru, which has allowed to families who had had minimal access to any kind of animal protein to increase it steadily in the last 20 years. 
During this period of time, the actions promoted by the Peruvian Poultry Association (APA) have generated production to grow from 400 thousand tons annuals to almost 2 million tons annually. In parallel, the annual consumption of low-income families has been increased from $10 \mathrm{~kg}$ per year to $35 \mathrm{~kg}$ per year. On the other hand, this initiative has also improved the health safety of poultry meat.

The objective of the research has been to analyze this case study with the purpose of extracting from it some lessons that can be recommended for the creation of food production systems that have an impact on the prosperity of populations with low resources in emerging countries. In this sense, the research question has been formulated as: What strategy can ensure the sustainability of food production systems that impact the prosperity of populations with fewer resources from emerging countries?

To analyze this experience, we have used the Working With People (WWP) framework [2], a methodology previously validated for the analysis of the sustainability of production systems and its contribution to the prosperity of rural populations [3,4]. This methodology allows identifying the critical variables of the success of an experience through the analysis of its three dimensions: territorial-contextual; technical-business; and ethical-social.

The analysis of the case study under the WWP methodology shows that an initiative of an association of companies can generate a system of food production that benefits the low-income people of an emerging country. This analysis underscores the objective of the business initiative must focus on the prosperity of society.

At the same time, this case validates the assertion that the strategy of a food production system that contemplates the three dimensions of the WWP model ensures the sustainability of a system that impacts the prosperity of low-income populations in an emerging country.

The article has been structured collecting, in the first place, some experiences on the sustainability of food production systems; then the methodology used has been described, including a detailed description of the case, its conceptualization and the elements that demonstrate its sustainability; thirdly, the case analysis under the WWP model is presented under its three dimensions.

\subsection{Sustainability: Relevance and Scope}

Two important controversial issues impact the present times: on one hand, the rapid increase of environmental challenges caused by the climate change and a greater awareness of the environmental impact; and on the other hand, the ethical requirement to contribute to prosperity of low-income population: poverty eradication and hunger [5]. Also, this dilemma needs to be solved in the medium term. At current growth rates, by 2050, an increase of between $60 \%$ and $110 \%$ in global food production will be needed [6]. And this increase will take place in a context of climate change and without compromising resources needed to serve future generations. Parallelly, according to the World Bank, the number of people under the poverty line of US\$ 1.90/day in the world has increased in $2.5 \%$ between 2016 and 2017: increasing to 768 million of people [7].

For Rockström et al. [6], the solution to this dilemma must focus on the transformation of intensive agricultural systems, so that agriculture ceases to be the biggest global change factor to become a key contributor in the transition to a sustainable world. However, as Brklacich et al. presented, the concerns about the sustainability of food production systems is not only be confined to agriculture systems and their impact in the environment degradation [8].

These authors presented in 1991 a detailed and exhaustive review of the academic literature about different dimensions for the concept of sustainable food production systems [8]. Thus, they found out that six major themes underpinning sustainability: environmental accounting, sustained yield, carrying capacity, production unit viability, product supply and security, and equity [8].

Environmental accounting refers to biophysical limits for agricultural systems and has been presented as the most important theme for sustainability [8]. Sustained yield describes the group of conditions that would stabilize crop yields from year to year [9]. This theme was extended to agricultural activities from the forest sector. 
Carrying capacity refers to the maximum population size who could use a site without causing permanent damage to the natural environment. However, as Brklacich et al. pointed out, the estimation of population that may be supported by a particular site is affected by the interactions among a wide range of socioeconomic, behavioral, and biophysical factors. This way, "estimating population size which can be supported by a particular region is central to measuring the sustainability of food production systems" [8] (p. 7).

Production unit viability focuses on the performance and viability of individual farms. "The viability of farms is an important concern within the broader context of sustainable food production systems. Without adequate economic rewards for agricultural producers, it will be increasingly difficult for farms to remain in food production system" [8] (p. 8).

Product supply and security means the adequacy of food supply levels to meet the population minimal requirements for nutrition and satisfy cultural demands or dietary preferences. In fact, food security cannot be reduced to just one economic activity: food is a complex matrix that demands a holistic approach to capture the complexity of nutrition and its impact on health $[10,11]$.

Equity refers "to fair access to production opportunities and a balanced distribution of production costs, goods, and services associated with resource use" [8] (p. 9). This way, it is a common requirement that enhancing prospects for sustainable food production must include conditions for improving living conditions for the least advantaged groups within society: "increasingly, a secure food supply that is accessible to all members of society is being recognized as a vital component of a sustainable food production system" [8] (p. 9).

There are authors who recognize there cannot be sustainability without inclusion. A system of food production cannot be sustainable if it is not equitable: if it does not meet the basic needs of all, and at the same time, it opens opportunities to improve their quality of life. Not doing so would mean being exposed to the problems of major migrations, geopolitical crises, and social conflicts [12].

Equity has also an intergenerational level of application. The concern is "meeting the needs of the present without compromising the ability of future generations to meet their own needs" [13] (p. 43). This is also recognized by Food and Agriculture Organization (FAO): the sustainability of an agricultural system implies ensuring food security and nutrition for all now and in the future [14].

Brklacich et al. propose a definition of sustainable food production system: "an agri-food sector that over the long term can simultaneously: maintain or enhance environmental quality; provide adequate economic and social rewards to all individuals and firms in the production system; and produce a sufficient and accessible food supply" [8] (p. 10).

Keoleian and Heller [15] argue that improving the sustainability of food production systems requires a clear understanding of the relationships between the behavior of population consumption, food processing, distribution activities, and production practices. Thus, these authors conclude that an adequate understanding of the life cycle of the product is a very useful tool to understand the existing relationships between social needs, and social and natural processes. These relationships allow understanding those needs and the environmental impact of the satisfaction of said needs.

Another factor mentioned in the academic literature for the sustainability of the productive system is the impact of food on public health. The current concern is given by the appearance or reappearance of human diseases that are of zoonotic origin. Even the term One Health is used to refer to the essential relationship that exists between human health and animal health. In this sense, a practical recommendation is the reduction of the use of antibiotics in the care of animals [10].

This multiplicity of social and productive factors implies that responsibility for the sustainability of food production systems does not rest solely with the state. Van Meijl, Ruben and Reinhard [12] argue that sustainability is everyone's job and that the business sector is called to participate in it, making inclusion and sustainability part of the company's core values. On the other hand, Verburg et al. [10] argue that food security is linked to government policies, that is, a strategic vision that looks at the long term, and therefore demands a governance approach: an adequate interaction between 
the state, the market and the civil society $[14,16]$, and effective institutions to obtain good results in sustainable agricultural development strategies [14].

\subsection{Prosperity}

Prosperity has been conventionally defined as the economic growth, but this definition has not been able to account for the negatives environmental consequences, serious material impacts that compromise future possibilities and lack of opportunities for all. A prosperity focuses on few people, and founded on ecological degradation and steadily social injustice is not appropriated for a fair society [17].

From this point of view, Jackson [18] has popularized a new approach of prosperity: the human beings flourishing, the achievement of greater social cohesion and higher levels of well-being while reducing their material impact on the environment.

Indeed, he accepts that prosperity has material dimensions to ensure adequate supply of food, shelter, clothing, water, etc. without an environmental degradation. But, he also explains that a human being is also affected by psychological and social dimensions. Thus, everyone needs a meaning and purpose in life, and to participate in building on the common good of one's community: working usefully, enjoying respect to other people, or voluntarism. In other words, a sense of community and meaningful work is essential: "ensures nutritional health, takes part in the life of the community, uses their education, finds worthwhile jobs, appears in public without shame, visit friends and relations" [19] (p. 15).

This vision of prosperity may serve us to precise the most well-known and well-used dimensions of sustainability for food production systems: economic, social, and environmental. "The economic, social and environmental have been the most well-known and well-used pillars of sustainability" [20] (p. 13). For example, when Castellini [21] compared three poultry production systems, he defined the social dimension as labor safety, this is, he only took into account the impact of the different production processes on worker health, and not how those systems are socially affecting the whole society.

\section{Methodology}

The methodology used was the analysis of a case study that occurred in an emerging country. The access to official information and also the access to the most relevant actors of this case has allowed assuring the internal and external validity. In fact, each step of the analysis process has been documented to ensure its reliability [22]. The APA case study is located in Peru, a country in South America with an area of more than 1,200,000 km² and also with a complex geography (Figure 1).

The objective of the research has been to find out the variables that can ensure the sustainability of a food production system that contributes to the prosperity of low-income families of emerging countries, and the methodology used for this analysis has been the WWW framework.

WWP proposes a 'new approach' for sustainability and prosperity in postmodernity in rural and food production systems. Key to the WWP model is 'planning as social learning' and a 'new postmodern sensibility' $[2,23,24]$. The name Working With People was chosen to convey the need to overcome the traditional technical-economic vision of prosperity, and the need to focus on individuals' behavior and the context in which they work.

In 2016, the WWP framework has been validated as an instrument to analyze rural development, rural prosperity and resilience in a world of growing demands and limited resources. This validation was done under the international RETHINK research program supported by European Commission and funding bodies in 14 countries under the FP7 and the RURAGRI ERA-NET called RETHINK [3,4]. "The research members of Rethink formed a multi-sectorial and inter-disciplinary Expert Panel to create the reporting guidelines on each theme. The Expert Panel provided research advice on effective strategies and ways of rural prosperity and established the common guidelines for the creation of questionnaires based on the methodological framework Working With People (WWP)" [3] (p. 87). 


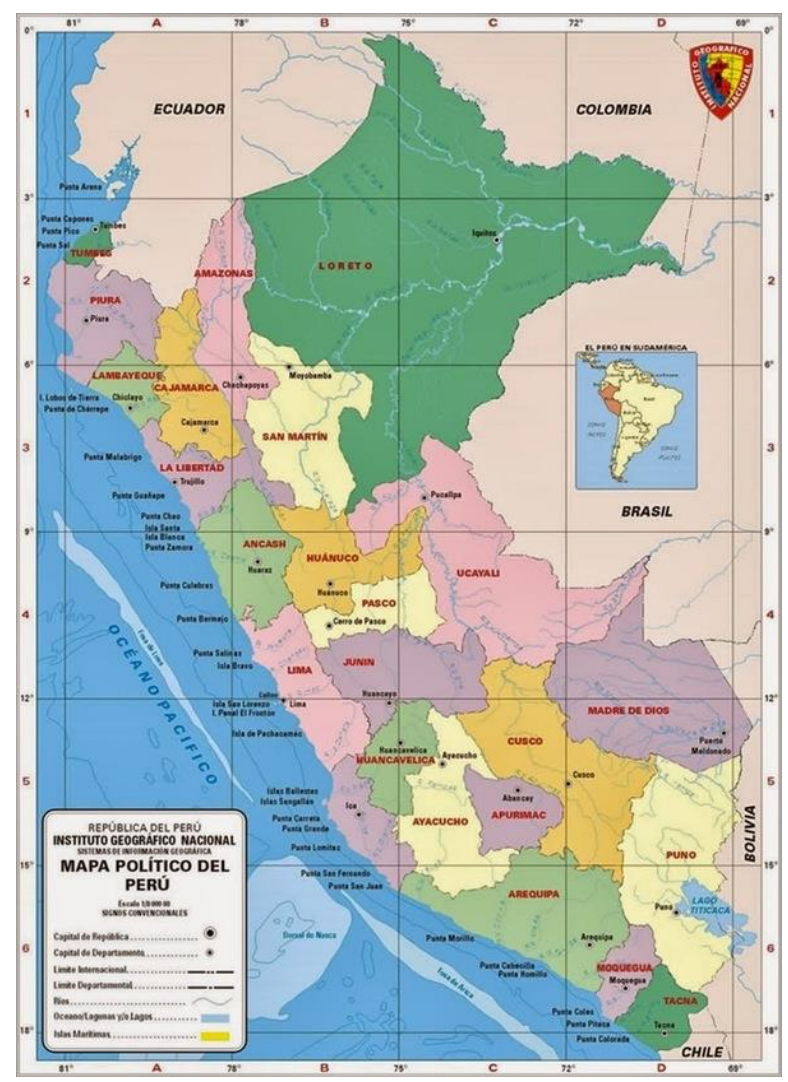

Figure 1. The political map of Peru. Source: National Geographic Institute.

The WWP model seeks to integrate expert knowledge with experienced knowledge, and also connect knowledge with action, but incorporating the values of the different participants of the flow of goods or services of any project [3].

In this sense, this model considers behavioral competences and a solid ethical basis; contextual competencies; and technical competencies as key elements for the sustainability of a system that has an impact on the prosperity of a society [3]. This methodological framework goes beyond the technical-economic view, and integrates social learning processes in the analysis and the building of prosperity from three dimensions: ethical-social, technical-entrepreneurial and political-contextual. These three components interact through social-learning processes (Figure 2), and include the four fields of a social-relationship system, as defined by Friedmann [25]: the political field, the public administration field, the private and entrepreneurial field, and finally the civil society field. The apparent simplicity of WWP involves a large social complexity [2] given the richness of the relationships and lessons that occur between the three components of the model.

From the Political-contextual dimension, organizations involved ought to adapt their priorities and their projects in the context in which they work to achieve sustainable management [3]. This dimension covers the ability to make relations with political organizations and with the different public-administrations that enhance sustainable development and thereby foster the prosperity of rural areas and its agricultural communities. The design of modern strategies for the sustainability of a food production system requires social integration and anticipating the long-term trends affecting rural areas. The configuration of WWP strategies for the sustainability must ensure that organizational change processes and structural processes are generated to allow adaptation to the priorities of involved people, also working with actors from the political and public administration fields. WWP organization has, therefore, an instrumental character, to serve the population, and it is flexible and changing according to the learning and the new information generated. This way, the WWP organization becomes a living entity, which transmit values to society-from its ethical component-and is capable of 
influencing and changing political priorities and to work together to achieve sustainable management. This political-contextual dimension builds on the understandings of prosperity as capabilities for flourishing $[18,26]$.

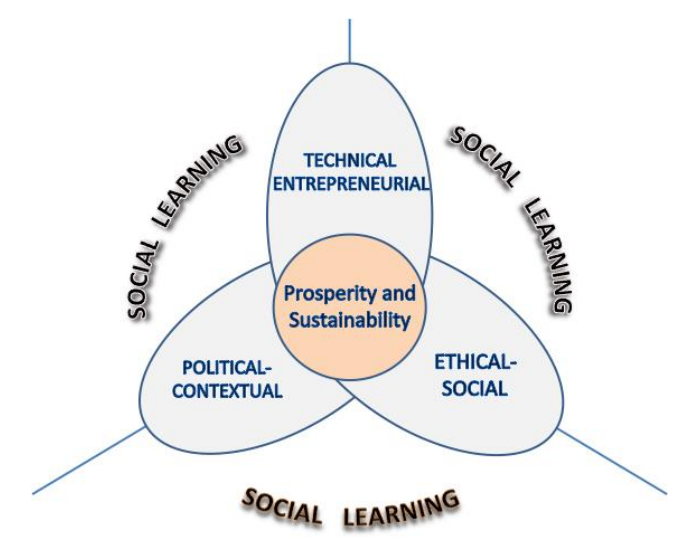

Figure 2. Dimensions of sustainability and prosperity from the WWP model. Source: [2]. With authors' permission.

The Technical-business dimension is oriented towards the generation of sustainable products and services for the society based on quality standards and providing environmental, social and economic benefits. From the point of view of social relations, this dimension corresponds to the private-entrepreneurial field, which comprises all activities of private initiative. The WWP project adopts a "business function" — as mobilizing human, economical, public, private resources—leading to the arrangement and negotiation between various actors and involves a commitment to assume and manage risk. This technical-business dimension exceeds economic imperative and include social and environmental criteria $[27,28]$ and multi-stakeholder business governance to creates rich social networks that allow new sustainable strategies [29], recognizing that-given a diminishing marginal utility of goods-"more is not always better". Given this view, the merely commercial and financial aspects of WWP project are exceeded; it serves not only to achieve "tangible" benefits to care about the "intangible" benefits in the form of expansion of knowledge, and social and cultural aspects to develop sustainable solutions [2].

And from the Ethical-social dimension considers the context of behaviors, attitudes, and values of people who interact throughout production processes. This component is identified with the social subsystem, consisting of all interpersonal relationships that are taking place within society. The ground of the social system that surrounds WWP project is to cover conduct and moral behavior of stakeholders and it sets out the "foundations" to make people, both from private and public fields, come to work together, with commitment, confidence and personal freedom [2]. The incorporation of ethics, means considering the project as not 'neutral', but based on an ideal of service and guided by values. This dimension integrates behavioral competences with ethics and values as appropriate elements to overcome potential moral conflicts related to the interested parties involved in the project [30]. The WWP project seen from this dimension tries to achieve the best for a greater number of people, especially the poorest people with few resources and the participation of the beneficiaries for the effective sustainable development and modernizing the farming practices, like sustainable food systems.

Finally, the integrating dimension of the three dimensions is social learning [25]. These dimension to ensure social learning processes among the different subsystems, which lead to learn from the real agents of change. The social learning process runs with the main assumption that all effective learning comes from the experience of reality change. The population affected by the project actively participates in planning, with their own behaviors, attitudes and values—ethical-social component- to promote and manage the WWP project. Therefore, it requires to generate actions directed to integrate the 
experienced knowledge [31] of the affected population, along with the planner's expertise, providing mutual learning. To do so, reliability is essential among the agents of the different social subsystems, generated from responsibility, a proper behavior, rigor, trustworthiness, and an open and consistent attitude [30]. Similarly, to ensure these social learning areas and processes, it requires to have a proper appreciation of values, defined as the ability to understand the inherent qualities of others and understand their points of view. This leads us again to say that ethics and behavior of people involved are the basis of WWP project.

According to the principles set up within the WWP framework, the analysis has been made from two types of data: qualitative and quantitative data. First, during the last six years there have been several interviews with the key actors of this intervention. In 2003, an interview was conducted with the Director of National Agrarian Health Service (SENASA), who previously was the head of Animal Health in 1996, and the person who represented SENASA at the beginning of the relationship with APA. Also, an interview was conducted with the person of APA who represented the association in that relationship. Additionally, another interview was undertaken with the CEO of APA. Then, to ensure full and complete participation of the different company sized members of APA, a fourth interview was carried out with one of the CEOs of the smallest company members of APA. In 2015, the CEO of APA was interviewed again. All of these interviews were recorded.

Then, in 2018, and in order to update the data for this research, a focus group was carried out with the President of APA; the CEO of APA; the person in charge of the market access project of APA (who was the first head of the national program of Poultry Health by SENASA, in 2004); and the head of the poultry and egg committee of APA. Then, a phone interview was conducted with the CEO of the leading company of the sector, and finally a last interview was carried out with the President and the CEO of APA.

For all of these in-depth interviews, semi-structured questionnaires were prepared. The questions were divided into the three dimensions of the WWP framework: territorial-contextual, technical-business, and ethical-social in order to recognize the key variables of the APA initiative on each one of these dimensions. The interviews were conducted face to face with the stakeholders involved.

Information was also obtained from previous investigations, statistics and official documents of the government of Peru, which were collected to examine the evolution of APA actions and their impact on the sustainability of a food production system that benefits the population of fewer resources in the country.

To ensure the internal validity of the case, a quantitative analysis was carried out based on the National Household Survey (ENAHO), which the National Institute of Statistics and Informatics (INEI) performs each year at the national level with the intention of measuring, individually and by family, different attributes of the population. This survey has modules on employment, health, income, expenses, consumption, among others, which have representation at the national, regional, rural, urban or geographical levels.

Specifically, Household Expenses module and the SUMMARY module for expenditures has been used. The data analysis software used has been STATA 15.0, and the methodology has had two parts: processing and calculation. The processing included the review and identification of the variables to be used and the household identifiers; the unification of the databases; and the creation of the necessary variables for doing the calculation. It also involved the estimation of the values of the different variables. In this way, as the sample is representative at a national level, the evolution of the average annual consumption of poultry by families between 2004 and 2017 were found for three segments: extremely poor, poor, and non-poor.

Regarding the limitations of the quantitative analysis, information is only available since 2004. On the other hand, the poverty categorization used by the INEI is based on the calculation of a poverty line linked to the monetary and non-monetary value of a basket of consumption appropriate to the circumstances of the respondent's region. 


\section{The Case of the Peruvian Poultry Association (APA)}

In 1998, the APA consisted of 13 contributing companies that accounted for more than $70 \%$ of the poultry production in Peru, however it included all the producer companies of poultry products in the country as members of the association. As part of its activities, the association held the representation of the companies of the sector before the government and organized, also collectively, several commercial campaigns. The factor that had most influenced the collective action was the success of the commercial campaign to spread the quality of the chicken raised in industrial farms.

In the years prior to 1998, companies in the sector had to face several crises: from a market of prices controlled by the State in the 1970s and 1980s, the market had switched to a system of free competition; the sector had stopped being exonerated the $18 \%$ of value added tax, an amount that had to be absorbed by the companies themselves, and that caused the bankruptcy of several of them. And finally, in 1996, the business association and twelve companies in the sector were accused of price agreements.

In 1998, the per capita consumption of poultry meat per year in Peru was $19.5 \mathrm{~kg}$, and represented the main source of animal protein consumed by Peruvians: $46 \%$ of animal protein. In addition, the sector represented $1.16 \%$ of the national GDP, and $14.8 \%$ of the agricultural sector [32].

It was in these circumstances that the APA board realized that poultry production and marketing was more than a simple exchange of consumer goods for an amount of money. If the need they were satisfying was a component of the prosperity of the Peruvian population, then they should act seeking the food and nutritional security of the entire population. With these concerns, they realized the importance of working to improve their productivity. Their main cost overrun was the expense caused by chicken diseases: drop in feed conversion, losses of chickens, and a high expenditure on medicines for chickens focused in carrying out a health control program. The APA board also considered that competition between companies in the sector would ensure the transfer of said savings to the consumer (Interview with the CEO of the leading company of the sector and interview with a member of the APA Board of directors in 1996).

In this way, the APA board decided to approach the National Agrarian Health Service (SENASA), the decentralized entity of the Ministry of Agriculture in charge of sanitary control. However, as SENASA did not have the poultry sector in its operational plan, it did not have the financial resources to run a vaccination program for domestic poultry, fowl and migratory birds. Therefore, the program had to be financed by private companies until public resources generated by a national sanitary regulation could be available. In this sense, it was also necessary to work on this regulation, which was estimated to go into effect in less than two years (Interview with the head of animal health of SENASA in 1996).

In these circumstances, the eight largest companies in the sector decided to finance this program for three and a half years, until the sanitary standard set a rate for all industrial poultry breeders (Interview with a member of the APA Board of directors in 1996).

\section{Results: The Analysis of the Case Study under the WWP Framework}

In order to demonstrate the research hypothesis of this work, the case study is analyzed under each one of the WWP dimensions: political-contextual; technical-business; and ethical-social. This analysis allows to identify the key variables and also to organize them systematically, so the model could be replicated in emerging countries. For this reason, first of all, the intervention's strategy has been drawn. Secondly, the key variables emerged from the different interviews conducted and the public information collected have been written down under the appropriate WWP dimension. 


\subsection{Political-Contextual Dimension: Conceptualization of the Intervention Strategy}

A first key element of the intervention strategy of this case (Figure 3) has been the adequate definition of the problem: the main cost overrun is due to the lack of sanitary control in poultries that are outside industrial farms.

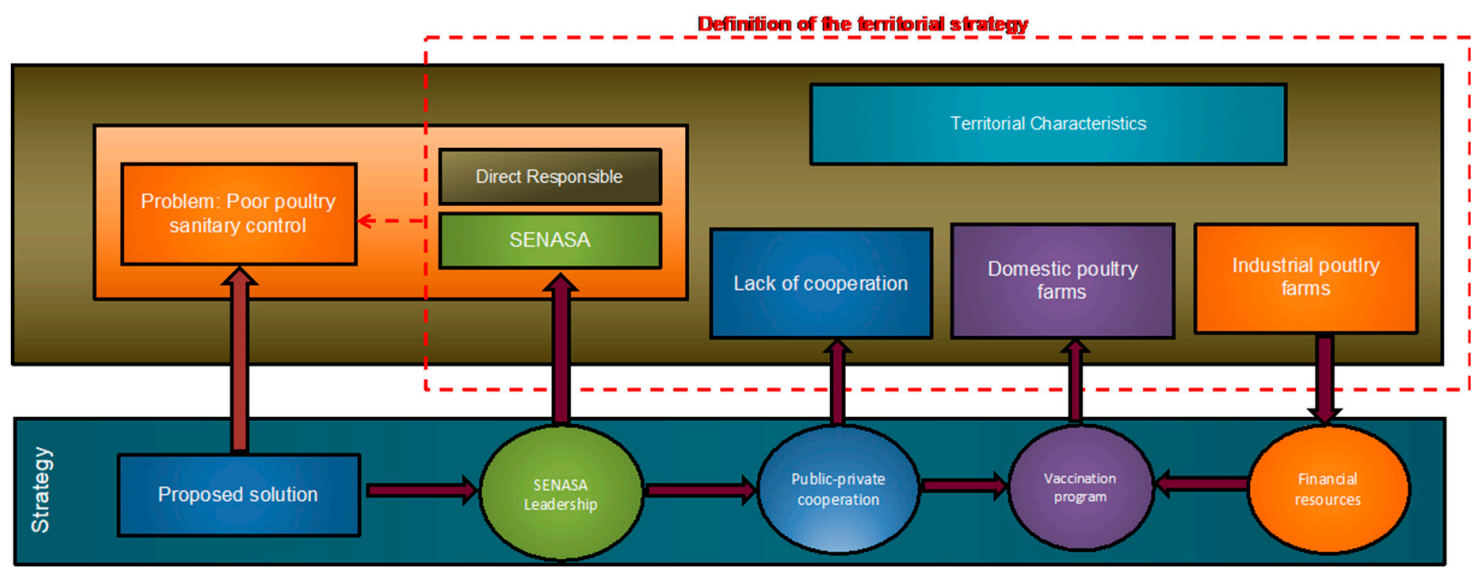

Figure 3. The definition of the intervention's strategy. Source: Own elaboration. SENASA: National Agrarian Health Service.

A second key element was the definition of the territory. An important aspect of the sanitary control program is the definition of the scope. Initially, the poultry companies considered necessary only the attention of the farms adjoining their farms. However, the SENASA staff helped APA to understand that the risk came from any poultry that was in the country, so that the measures had to be extended to the entire national territory, including domestic farms which raise poultries for self-consumption or for small commercialization scale, fowl, and migratory birds (interview with the head of animal health of SENASA in 1996).

A third key variable of this dimension has been the horizontal cooperation between the private companies in the sector. In 1998, APA had been in operation for 60 years, and the owners of the 13 associated poultry companies took an active part in the association. This horizontal cooperation was also manifested in the joint decision of the eight main companies in the sector to finance the vaccination program for three and a half years. "We started by asking the leader for his contribution, and when we had it, we told each of the rest if we could count on theirs because we already had the leader's contribution. Then each one said yes" (interview with an APA member of the Board of Directors in 1996).

Another key variable has been the public-private cooperation between APA and SENASA. Until 1996, there was no articulation between the companies in the sector and SENASA. Each one did his tasks according to his best criteria. The industrial farms worried about the running of their business, and they did not allow any public official to enter their facilities or share their information. In addition, as the international cooperation agencies did not grant loans for assistance to the poultry sector, in the annual plans of SENASA there was no such sector. And since the evaluation of public officials is based on compliance with the objectives and goals included in their annual plans, there was no reason to think about a health control program for the poultry sector. This cooperation required several attempts and efforts of the directors of both institutions. The Head of Animal Health of SENASA in 1996 commented: "It took two years of meetings and constant conversations between APA and SENASA to build trust and find a common vision for the future" (interview with a member of APA Board of directors in 1996 and the Head of Animal Health of SENASA in 1996).

Other key element of the intervention strategy was to give prominence to the direct people in charge: SENASA, who was in charge of the direction and management of the vaccination program for 
domestic and combat poultries, and migratory birds. Table 1 shows the number of animals vaccinated between 2003 and 2012.

Table 1. Number of vaccinated domestic poultry per year.

\begin{tabular}{|c|c|c|c|c|c|c|c|c|c|c|}
\hline Province & 2003 & 2004 & 2005 & 2006 & 2007 & 2008 & 2009 & 2010 & 2011 & 2012 \\
\hline Ancash & & & & & & & 1155 & & & \\
\hline Piura & & & & & & & & & 23,048 & 11,711 \\
\hline Ica & 2814 & 775,684 & 713,066 & 565,871 & 119,143 & 259,155 & 330,551 & 269,893 & 304,294 & 291,667 \\
\hline Cajamarca & & & & & & & 6 & 16,023 & 3877 & 3135 \\
\hline Arequipa & 142,428 & 300,671 & 321,554 & 273,950 & 39,923 & 245,205 & 202,111 & 125,490 & 83,466 & 217,537 \\
\hline Lambayeque & & & & & & & 310 & & & 17,477 \\
\hline La Libertad & 321,137 & 156,763 & 353,217 & 706,255 & 138,115 & 392,331 & 444,430 & 299,736 & 464,396 & 519,172 \\
\hline Madre de Dios & & & & 1071 & & 1304 & 4443 & & 9530 & 348 \\
\hline Moquegua & & & & & & & 2349 & & & \\
\hline Lima y Callao & 30,639 & 519,266 & 536,805 & 828,100 & 69,905 & 308,007 & 514,716 & 137,949 & 592,642 & 793,016 \\
\hline Puno & & & & & 1297 & 17,268 & & & & \\
\hline Tacna & 13,584 & 4501 & 2677 & 5853 & 8541 & & 62,135 & 44,606 & 76,831 & 57,842 \\
\hline Apurimac & & & & & & & 1960 & & 4132 & 11,602 \\
\hline Total & 510,602 & $1,756,885$ & $1,927,319$ & $2,381,100$ & 376,924 & $1,223,270$ & $1,564,166$ & 893,697 & $1,562,216$ & $1,923,507$ \\
\hline
\end{tabular}

The last key perspective of this dimension has been the articulation of the four social actors: the business sector, public administration, the political sphere, and civil society. This articulation was essential for the design and promulgation of the national sanitary control system with an international standard, that was given in 2007. The promulgation of this norm signified an articulation plan, which had as its origin, the work between APA and SENASA (Interview with the general director of Animal Health of SENASA in 1996). The Figure 4 shows the most important events during all the process.

\begin{tabular}{|c|c|c|c|c|c|c|}
\hline Event & $\begin{array}{c}\text { Beginning of } \\
\text { conversations between } \\
\text { APA-SENASA }\end{array}$ & $\begin{array}{c}\text { Signature of the } \\
\text { agreement between } \\
\text { APA-SENASA }\end{array}$ & $\begin{array}{c}\text { Beginning of the } \\
\text { vaccination program }\end{array}$ & $\begin{array}{c}\text { Beginning of the } \\
\text { National Health } \\
\text { Poultry Program }\end{array}$ & $\begin{array}{c}\text { Declaration as free } \\
\text { avian influenza } \\
\text { country }\end{array}$ & $\begin{array}{c}\text { Regulation of the } \\
\text { Poultry Health } \\
\text { System }\end{array}$ \\
\hline Year & 1996 & 2000 & 2002 & 2004 & 2005 \\
\hline
\end{tabular}

Figure 4. The relation of the most important events during the process. Source: SENASA, 2010. The management of SENASA for the poultry health system: roles and obligations. Own elaboration. APA: Peruvian Poultry Association.

In this way, from the perspective of the planning of the public sphere, the intervention has been characterized by having two complementary movements. A bottom-up movement: the private initiative at the beginning of the intervention, typical of Social Learning planning model [25] and a top-down movement: the securing of public recourses and the action of SENASA, typical of Policy Analysis planning model [25]. The WWP model [2] proposes that in order to ensure the sustainability of an intervention in a given territory, both planning models are required.

\subsection{Technical-Business Dimension: Results and Sustainability of the Production System}

Regarding the technical-entrepreneurial dimension, the relevant variables have been the generation of a sanitary control system and a series of actions to improve the productivity of the sector. For the Head of Animal Health of SENASA in 1996, the most significant result of this intervention has been the generation of a sanitary control system that was defined with the new poultry health regulation, which was enacted in November 2007.

For the generation of this health control system, the initial financing of the largest companies in the sector played a relevant role. However, the sustainability of this system depends in a determining way on public resources that are generated from a mandatory rate for all industrial farms. 
The improvement of productivity is also a consequence of geo-referencing all of the 1500 poultry farms in the country; the nationwide enumeration of the 45,000 domestic farms and fowl breeders; the annual vaccination of approximately 2 million domestic poultries; the surveillance of poultries in small farms, domestic breeding and migratory birds of 11 wetlands.

Another relevant technical variable for the sustainability of this production system has been a feature of the system that companies in the sector have known how to hold: the short value chain. The Peruvian market has always been characterized by consuming only the chicken that has been benefited on the same day. This causes that in Metropolitan Lima, a city of 9 million inhabitants, daily benefit and distribute between 750,000 and 1,000,000 chickens in the 7195 poultry sale stalls, in a window of time that only goes from 3:30 a.m. at 8:00 a.m. (interview with the President of APA in 2018; interview with a poultry distributor and owner of sale stalls) [33,34].

In relation to 1998, the production of poultry meat has multiplied by 5.8, as shown in Figure 5. At the same time, annual per capita consumption has gone from $19.5 \mathrm{~kg}$ in 1998 to $50.52 \mathrm{~kg}$ in 2017 (Figure 6); and in that period, it has been the animal protein that has shown the most internal consumption (Figure 7).

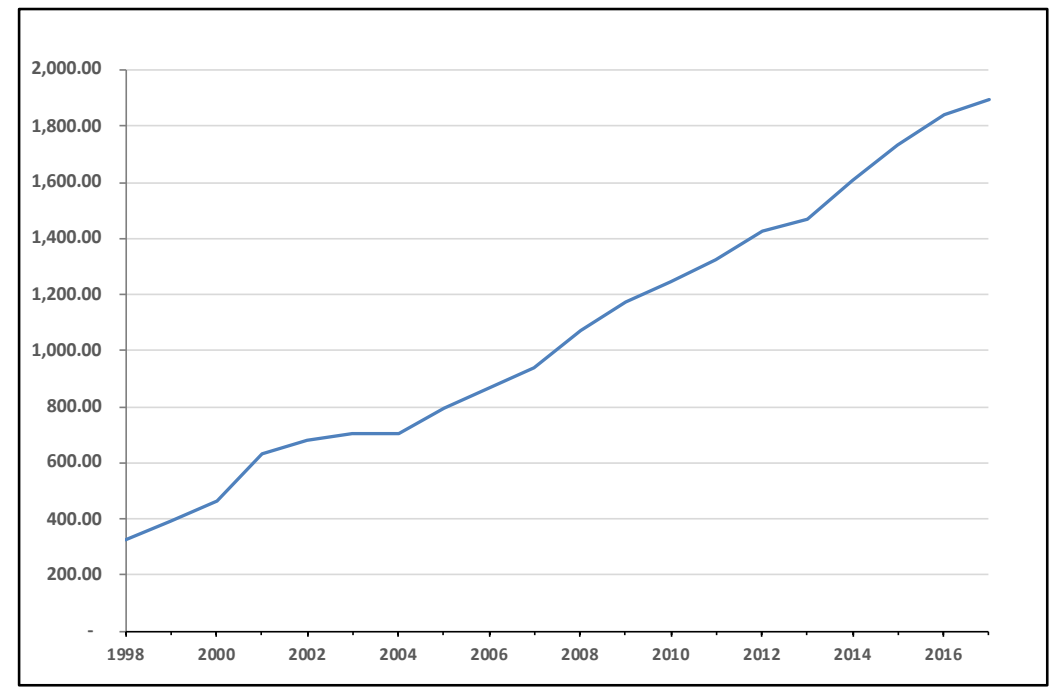

Figure 5. The evolution of poultry meat production. Source: Agrarian Regional Directions - Direction of Agrarian Information. Ministry of Agriculture and Irrigation (MINAG). Own elaboration.

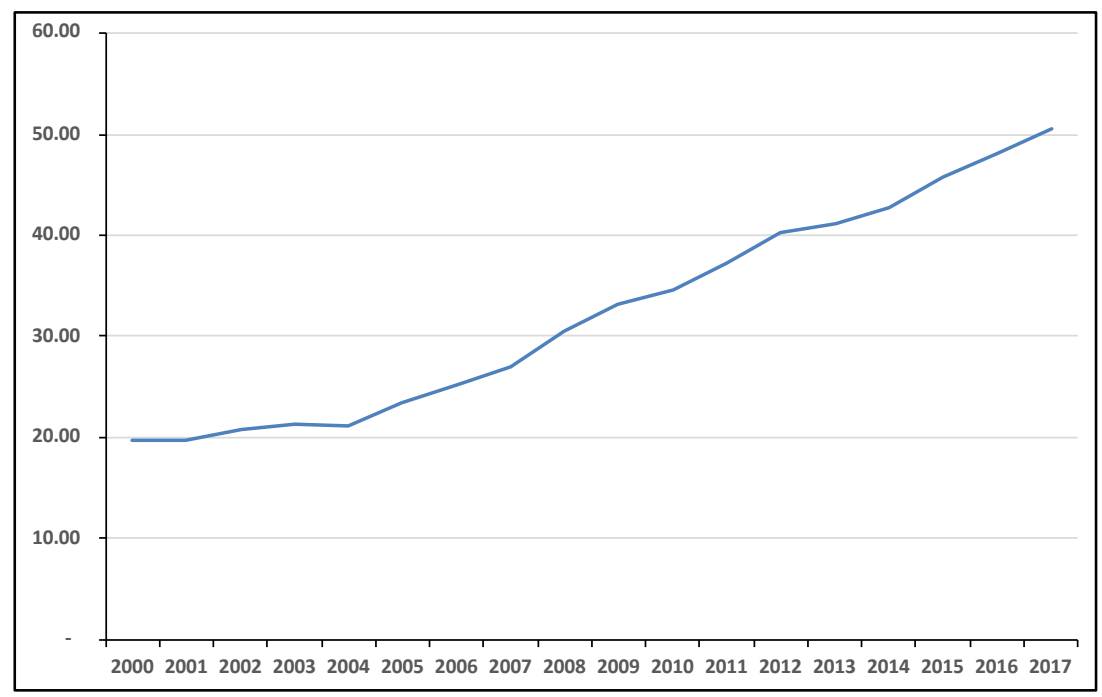

Figure 6. The evolution of internal demand of poultry meat. Source: Agrarian Regional Directions-Direction of Agrarian Information. MINAG. Own elaboration. 


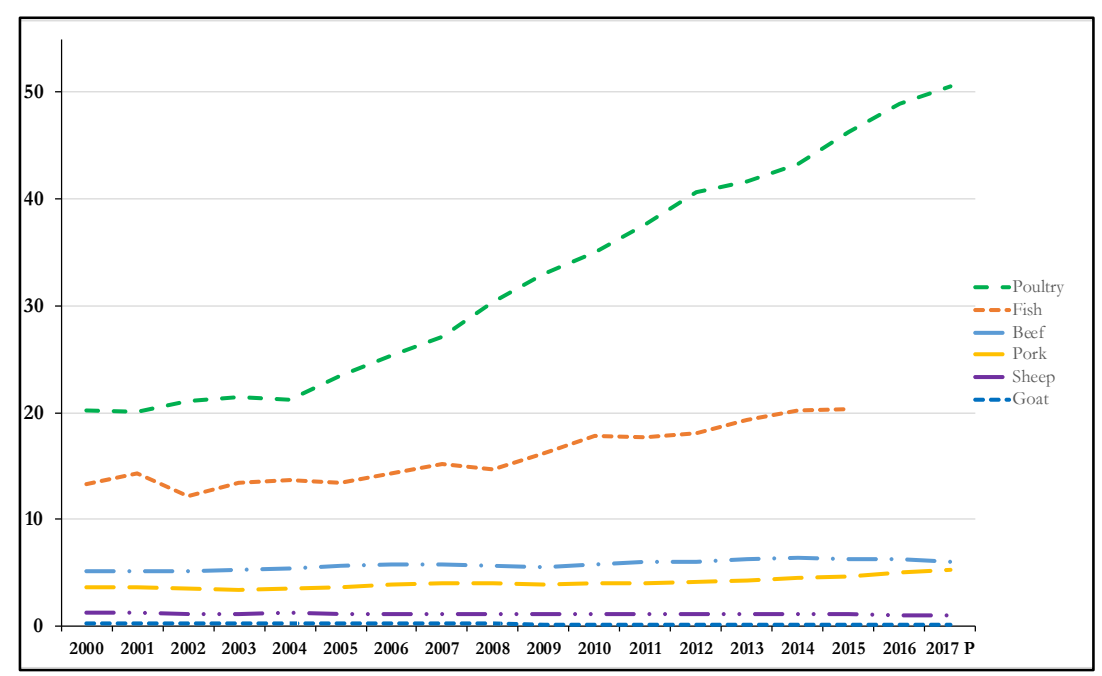

Figure 7. The evolution of internal demand for different types of source of animal protein. Source: Regional Directories of Agriculture; Ministry of Production (Produce); FAO; MINAG. For 2017, some results were still projected. Own elaboration.

On the other hand, in Figure 7 it can also be seen that the greater demand for poultry meat has not been at the expense of the consumption of the other sources of animal protein: it is a higher consumption for people who already consumed poultry or the consumption by people who previously had not consumed any type of animal protein.

Regarding the impact that this intervention has had on populations with fewer resources in the country, Table 2 shows the comparison of the evolution of the average consumption of poultry meat for extremely poor, poor, and non-poor households between 2004 and 2017. The three segments substantially increase their consumption: the extremely poor segment has an increase of $250 \%$; the one of poor, $27 \%$; and the one of non-poor, $20 \%$. The greatest impact of this production system is precisely in improving the diet of the population with the least resources in the country.

Table 2. Comparison of the evolution of poultry meat consumption in extremely poor, poor and non-poor families in Peru (kg/per family per year).

\begin{tabular}{|c|c|c|c|c|c|c|c|c|c|}
\hline \multirow[b]{2}{*}{ Year } & \multicolumn{3}{|c|}{ Extremely Poor } & \multicolumn{3}{|c|}{ Poor } & \multicolumn{3}{|c|}{ Non Poor } \\
\hline & Average & Inf. Limit & Sup. Limit & Average & Inf. Limit & Sup. Limit & Average & Inf. Limit & Sup. Limit \\
\hline 2004 & 10.40 & 9.24 & 11.55 & 55.52 & 53.31 & 57.72 & 85.37 & 82.77 & 87.97 \\
\hline 2006 & 8.83 & 7.80 & 9.87 & 52.04 & 49.64 & 54.43 & 93.62 & 90.92 & 96.33 \\
\hline 2007 & 8.83 & 7.67 & 9.99 & 49.98 & 47.58 & 52.38 & 95.10 & 92.79 & 97.40 \\
\hline 2008 & 29.08 & 25.23 & 32.93 & 71.68 & 68.30 & 75.05 & 113.81 & 111.46 & 116.16 \\
\hline 2011 & 27.33 & 24.67 & 29.98 & 67.89 & 64.67 & 71.12 & 111.00 & 108.87 & 113.13 \\
\hline 2012 & 30.08 & 26.48 & 33.69 & 67.44 & 64.42 & 70.46 & 109.38 & 107.35 & 111.42 \\
\hline 2013 & 40.22 & 36.65 & 43.78 & 77.98 & 74.14 & 81.82 & 106.23 & 104.55 & 107.90 \\
\hline 2014 & 28.73 & 25.50 & 31.96 & 69.85 & 66.76 & 72.94 & 106.41 & 104.79 & 108.02 \\
\hline 2015 & 30.56 & 27.58 & 33.55 & 67.05 & 63.65 & 70.45 & 103.51 & 101.94 & 105.08 \\
\hline
\end{tabular}

Source: Own elaboration since National Household Survey (ENAHO) data.

In the extremely poor segment, the positive impact has also occurred in the subsistence family economies of the rural areas of the country. These families usually raise poultry in order to have a product that they can commercialize in case of facing an illness or a special celebration. As the sanitary control program has had a national scope, these families have been also benefited, because the program 
has reduced the mortality of their chickens (Interview with a member of the APA Board of directors in 1996).

On the other hand, Figure 8 shows the evolution of the problem of anemia and child malnutrition, detailing its effect in the rural area. The improvement and positive evolution of the ratios of anemia and chronic child malnutrition in Peru are due to a series of activities carried out by the State to improve the living conditions of children: supplementing the infant diet with micronutrients; better control of their development; vaccination and education campaigns. But to these activities, greater access to food must also be added. The Demographic and Family Health Survey shows that in 2004 the percentage of infants who received some type of animal protein was $61 \%$; the year $2013,65.8 \%$; and the year 2017, 69.8\% in nursing infants and 94\% in non-nursing infants [35].

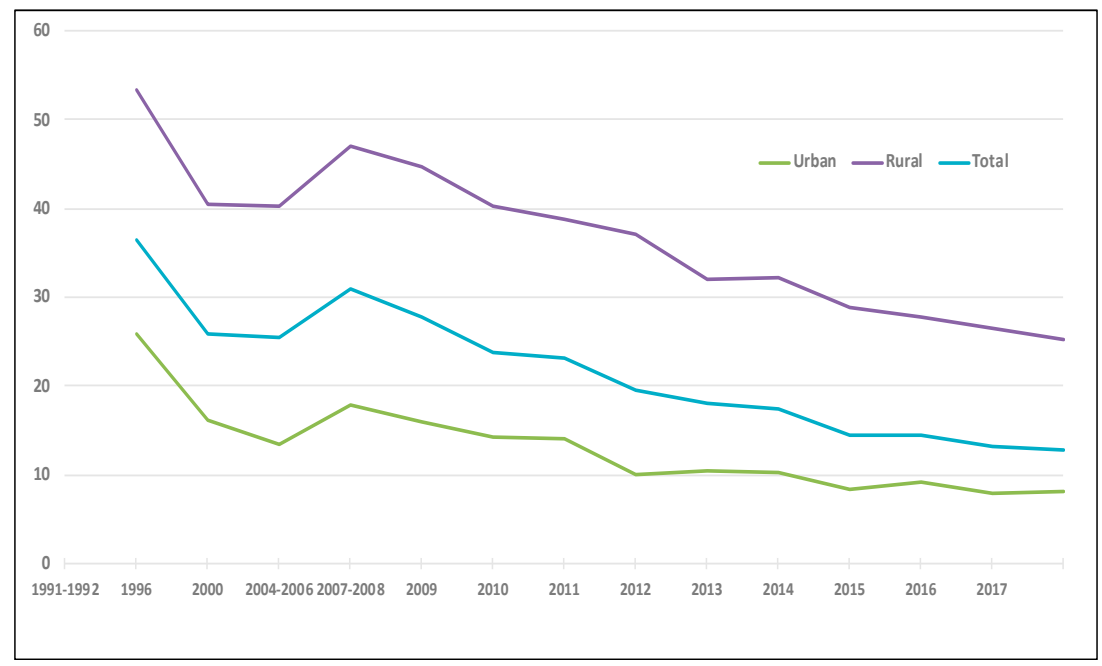

Figure 8. The evolution of infant malnutrition in children under five years of age according to area of residence in Peru (\%). Source: National Statistics and Information Institute (INEI). Demographic and family health survey.

It should also be mentioned that the national health system implemented by the APA initiative has resulted in a decrease in the consumption of antibiotics to combat poultry diseases. This decrease in the use of antibiotics improves the safety of this protein source (Interview with the President of APA 2018).

The Head of Animal Health of SENASA in 1996 also commented that thanks to this joint work between APA and SENASA, avian influenza did not enter Peru, despite having appeared in Chile and Colombia. As a result of this, the declaration of an avian influenza-free country was given in June 2005, and the possibility of entering the Japanese market in December of that same year.

Carranza [36], former Minister of Economy of Peru, pointed out that there have been few sectors in the Peruvian economy that have gained this level of productivity. In a national conference, he explained the poultry sector has been able to manage external shocks, to improve the food safety conditions and to work together with the public sector.

The sustainability of this food production system is manifested in the results obtained in the production of poultry meat in the last 20 years; in the increase of the animal protein consumption of the populations of fewer resources; in improving the safety of this protein source; and in the impact it has had on the prosperity of society.

\subsection{Ethical-Social Dimension}

This dimension has been present in a transversal way throughout the intervention, however, the social awareness that has had the largest companies in the sector has been essential. Several authors suggest that business associations are instruments to face similar problems in several companies [37-42]. 
On the other hand, as the cooperation between them in a common objective to the sector, it does not mean that each company does not maintain its own competitive objectives, these common interests can respond to strategies that benefit only the dominant companies in the industry [43].

In this sense, the performance of the APA has had a different objective. Moved by a social sensibility, the association has acted focused in the search of the prosperity of the Peruvian population with fewer resources. The CEO of the leading company commented: "If we could do something to contribute to prosperity of people with fewer resources, we had to act on it. It is an important food for people" (Personal phone interview).

So that they asked themselves how they should manage this business. What objectives should companies pursue in the sector? and what specific actions could be promoted from the APA to contribute to the improvement of families with few nutrition resources? (Interview with the President of the APA in 2018).

This interest for contributing to prosperity of the national population also was concerned to some of the SENASA officials. The head of Animal Health of SENASA in 1996 commented that he was one of those who considered that public administration should be involved with the private sector in the sanitary control of the poultry sector: "the agrarian health is a public good, and it claims pretty much that all of us work for it. It is about serving society as a whole" (Interview with the head of Animal Health in 1996).

On the other hand, this cooperation did not alter competition among companies in the sector: Carranza [36], argues that it has been a highly competitive sector. In addition, these measures did not harm small companies in the sector either. Referring to the mandatory rate for industrial farms, the general manager of one of the small companies of APA commented: At the beginning, there were many interpretations. Some of the directors of small businesses thought it would be restrictive for small companies. However, it was finally seen as a self-assessment, in order to regulate ourselves, and be more competitive. And he added: "the disease eradication program was not a measure of the dominant companies in the sector to prevent the growth of small ones. There was no bad intention. SENASA regulated and ordered the sector" (Interview with the general manager of a small associated company).

\section{Discussion}

The objective of this research has been to analyze the case of the APA initiative in order to draw the key variables which have to be taken in account to create a sustainable food production system, that impacts positively on the prosperity of low-incomes families in emerging countries. For this reason, the research question was set as what kind of strategy can assure the sustainability of a food production system which impacts the prosperity of low-resources people in an emerging economy.

The literature review has suggested to start out our analysis for the sustainability of a food production system using the definition proposed by Brklacich et al.: "an agri-food sector that over the long term can simultaneously: (1) maintain or enhance environmental quality, (2) provide adequate economic and social rewards to all individuals and firms in the production system, and (3) produce a sufficient and accessible food supply" [8] (p. 9).

Also, this analysis considers the definition of prosperity proposed by Jackson [18] and the theoretical framework of WWP. Thereby, the analysis of this study case allows plotting the main features of a strategy for the sustainability of a food production system targeting the prosperity of low-income populations in an emerging country.

Now, we are going to discuss these features of this strategy. First, the strategy starts out from a food production system which is itself environmentally friendly. Broiler poultry is the most environmentally efficient livestock among lamb, beef cattle, eggs, swine, dairy (milk), and turkey. "chicken broiler is the most efficient with an input of $4 \mathrm{kcal}$ of fossil energy per $1 \mathrm{kcal}$ of broiler protein produced" [1]. Beef cattle varies between 20:1 and 40:1 and lamb raises up to 57:1 [1]. 
Also, producing $1 \mathrm{~kg}$ of beef requires about 43,000 L of water. In contrast, $1 \mathrm{~kg}$ of broiler chicken can be produced with $2.6 \mathrm{~kg}$ of grain, which requires approximately $3500 \mathrm{~L}$ of water [1].

Comparing the animal protein consumption of fossil energy to the plant protein consumption ( $1 \mathrm{kcal}$ of animal protein requires approximately 10 times the energy expended to produce $1 \mathrm{kcal}$ of plant protein) [1], Pelletier criticizes the statement of environmentally friendly given to the poultry livestock, and suggests to promote the consumption of plant [44]. However, as Pimentel also mentions, "it should be noted that animal protein is 1.4 times more nutritious for humans than plant protein" [1]. Thereby, for emerging countries where there are high levels of malnutrition, especially in rural areas, the broiler chicken should be accepted as an adequate supply of animal protein.

According to Van Mejil, Ruben and Reinhard [12], sustainability should be everyone's job and the business sector should be called to participate in it. The study case shows precisely this participation from the beginning of the initiative. Also, the companies' core values have been the engine of this initiative which has pursued the prosperity of the low-income people of the country.

Thereby, the study case shows that an initiative of business companies can lead to the creation of a sustainable food production system. This private initiative should satisfy some conditions:

First, sustainability and prosperity require a change of mentality in business men that allows them to establish public-private partnerships and links with civil society. Herrero et al. state that "business as usual investments in agriculture, although necessary are unlikely to deliver sustainable solutions as the world rapidly change" [45] (p. 822). The aim of that initiative should be the prosperity of the whole society, especially the low-income resource people.

Thereby, the social dimension of sustainability should concern the prosperity of society. For example, when Castellini [21] presents his comparative analysis of three poultry production systems, he considers labor safety as the social dimension of sustainability. Instead, the link between sustainability and prosperity allows understanding that a sustainable food production system cannot be built over an unfair social system [17], but over one which allows the human flourishing of the whole society [18].

Second, the initiative should accomplish adequately three dimensions: ethical-social, technical-business and political-contextual.

From the ethical-social dimension, it can be affirmed that in the strategy of the APA, this component plays an essential role both in the concept of the initiative and in its execution. Interpersonal relationships and behaviors lay the foundations for the managers and partners of the APA-together with other actors from the public and private spheres- to work and advance together towards the design of a strategy that ensures the sustainability of the production system of foods that impact on the prosperity of populations with fewer resources. These processes allow improving people's abilities and competencies, with ethics and values as fundamental elements to overcome possible moral conflicts and to work as a team.

This ethical requirement is according to the Brklacich, Bryant and Smit statement of their three-dimensional definition of sustainable food production system (SFPS): "by casting this three-dimensional definition for a SFPS in the context of long-term goals for agricultural land use and food production, the equity perspective transcends all the three dimensions [8] (p. 10).

APA has developed a strategy that influences the technical-business dimension of sustainability and prosperity, allowing the creation of a solid business structure that generates goods and services to society and the most vulnerable populations. The initiative has allowed to the companies to reduce production costs by cutting inefficient expenditures in medicines for poultry, and also by decreasing the number of death birds by pests. And this savings has been translated to consumer by decisions of the main companies and the high competition among all the companies in the sector. Thereby, the strategy has achieved a considerable increase of the broiler chicken market: the annual consumption has raised from $19.5 \mathrm{~kg} / \mathrm{hab}$ in 1998 to $50 \mathrm{~kg} / \mathrm{hab}$.

Thus, the strategy of the APA has firstly ensured the accomplishment of the second dimension of the Brklacich et al. definition of SFPS: provide adequate economic and social awards to all individuals 
and firms in the production system; and secondly, to fulfill simultaneously the third dimension of their definition: produce a sufficient and accessible food supply.

The study case, thereby, has accomplished the three components proposed in the Brklacich, Bryant and Smit definition of SFPS. However, the analysis of the APA experience with the theoretical WWP framework permits finding out unnoticed key variables for the Brklacich et al. definition of SFPS. This is the political-contextual dimension of the WWP framework.

The strategy of APA to ensure the sustainability of food production systems and generate prosperity also has an important political-contextual dimension, contributing to a strategic vision of its activity of territorial scope. From this dimension, the APA improves the sustainability of its food production system by complementing the actions of the business sector and public administration. These synergies and complementarities are especially effective when carried out from alliances based on trust, commitment, and reliability among partners, creating favorable environments for good governance of policies. The capacities of the managers of these associations to establish interrelations and negotiations between agents (public and private) of different levels (regional, national or international) and to form strategic alliances, is a key factor for sustainability and prosperity. The experience of the APA has generated horizontal cooperation between companies and cooperation between the business sector and the public sector, which have been relevant to the sustainability of their food production system.

In this way, the results confirm the need for a balance between the different dimensions of the strategy: ethical-social, technical-business, and political-contextual to ensure the sustainability of food production systems that affect the needs of populations with fewer resources.

Finally, the results also confirm the need for a balanced action among the different social actors to lead to effective solutions to problems. In general, the case shows that a private initiative, business or social, can solve a social problem. Therefore, from an academia perspective, it would be advisable to propose the generation of more private initiatives that focus on solving social problems.

\section{Conclusions}

The sustained success of this business association is achieved when, in addition to generating profitability in the associated companies, other values are generated that affect the improvement of the quality of life of people. The companies incorporate social and environmental values, and guarantee a means of subsistence for producers and businessmen, and cover the needs of the population.

The case of APA provides lessons of experience for the transformation of the conventional systems of government of the business associations, towards a greater sustainability. In other words, when businesses focus on the prosperity of low-income populations in an emerging country, a sustainable system of food production can be generated, and then positively impact the prosperity of these populations. The formation of a business association (APA) from the WWP model has managed to generate a food production system that affects the three dimensions necessary to ensure sustainability and prosperity.

The case study shows that an initiative of an association of companies can generate a sustainable system of food production when considering the three dimensions of the WWP model: political-contextual, technical-business, and ethical-social. In this way, it tries to answer the challenge posed by Brklacich et al.: "the design and implementation of analytical systems that can readily consider environmental, cultural, and economic conditions of particular region and simultaneously measure the implications of alternative futures for environmental quality, food supplies, and the well-being of individual producers" [8] (p. 11).

Author Contributions: Conceptualization and methodology, A.F. and I.d.1.R.C.; software, J.V.-P.; validation and formal analysis, A.F., I.d.l.R.C. and J.V.-P.; investigation, A.F. and J.V.-P.; resources, A.F., I.d.l.R.C., J.V.-P., J.U.-S., D.S.-P.; writing—original draft preparation, A.F.; writing—review and editing, A.F. and I.d.l.R.C.

Funding: This research was funded by Universidad de Piura. PAD Escuela de Dirección. We propose to APA to fund the APC. 
Acknowledgments: We would like to thank Apolonio Suárez and Mario Berrocal for their valuable collaboration. We also are grateful with Stephen Pereira for his style review.

Conflicts of Interest: The authors declare no conflict of interest. The funders had no role in the design of the study; in the collection, analyses, or interpretation of data; in the writing of the manuscript, or in the decision to publish the results.

\section{References}

1. Pimentel, D.; Pimentel, M. Food, Energy and Society; CRC Press: Boca Raton, FL, USA, 2008.

2. Cazorla, A.; De Los Ríos, I.; Salvo, M. Working with People (WWP) in Rural Development Projects: A Proposal from Social Learning. Cuad. Desarro. Rural 2013, 10, 131-157.

3. De los Ríos, I.; Rivera, M.; García, C. Redefining Rural Prosperity through Social Learning in the Cooperative Sector: 25 Years of Experience from Organic Agriculture in Spain. Land Use Policy 2016, 54, 85-94. [CrossRef]

4. Rivera, M.; Knickel, K.; de los Rios, I.; Ashkenazy, A.; Pears, D.Q.; Chebach, T.; Šūmane, S. Rethinking the Connections between Agricultural Change and Rural Prosperity: A Discussion of Insights Derived from Case Studies in Seven Countries. J. Rural Stud. 2018, 59, 242-251. [CrossRef]

5. Deaton, A. Health, Inequality, and Economic Development. J. Econ. Lit. 2003, 41, 113-158. [CrossRef]

6. Rockström, J.; Williams, J.; Daily, G.; Noble, A.; Matthews, N.; Gordon, L.; Wetterstrand, H.; DeClerck, F.; Shah, M.; Steduto, P.; et al. Sustainable Intensification of Agriculture for Human Prosperity and Global Sustainability. Ambio 2017, 46, 4-17. [CrossRef] [PubMed]

7. Ferreira, F. The 2017 Global Poverty Update from the World Bank. Available online: http:/ /blogs.worldbank. org/developmenttalk/2017-global-poverty-update-world-bank (accessed on 29 October 2018).

8. Brklacich, M.; Bryant, C.R.; Smit, B. Review and Appraisal of Concept of Sustainable Food Production Systems. Environ. Manag. 1991, 15, 1-14. [CrossRef]

9. Altieri, M.A. Agroecology: The Science of Sustainable Agriculture; CRC Press: Boca Raton, FL, USA, 2018.

10. Verburg, P.H.; Mertz, O.; Erb, K.H.; Haberl, H.; Wu, W. Land System Change and Food Security: Towards Multi-Scale Land System Solutions. Curr. Opin. Environ. Sustain. 2013, 5, 494-502. [CrossRef] [PubMed]

11. Dwivedi, S.L.; Lammerts van Bueren, E.T.; Ceccarelli, S.; Grando, S.; Upadhyaya, H.D.; Ortiz, R. Diversifying Food Systems in the Pursuit of Sustainable Food Production and Healthy Diets. Trends Plant Sci. 2017, 22, 842-856. [CrossRef] [PubMed]

12. Van Meijl, H.; Ruben, R.; Reinhard, S. Towards an Inclusive and Sustainable Economy; Wageningen University \& Research: Wageningen, The Netherlands, 2017.

13. WCED. Report of the World Commission on Environment and Development: Our Common Future; Oxford University Press: Oxford, UK, 1987.

14. FAO. Desarrollo Agrícola Sostenible Para La Seguridad Alimentaria y La Nutrición: ¿qué Función Desempeña La Ganadería? FAO: Rome, Italy, 2016.

15. Heller, M.C.; Keoleian, G.A. Life Cycle-Based Sustainability Indicators for Assessment of the U.S. Food System; Center for Sustainable Systems, University of Michigan: Ann Arbor, MI, USA, 2000.

16. Kooiman, J. Governing as Governance; Sage: Thousand Oaks, CA, USA, 2003.

17. Jackson, T.; Anderson, V. Redefining Prosperity-Essays in Pursuit of a Sustainable Economy; Earthcan: London, UK, 2009.

18. Jackson, T. Prosperity without Growth: Economics for a Finite Planet; Routledge: London, UK, 2009.

19. Darnhofer, I.; De los Ríos, I.; Knickel, K.; Koopmans, M.; Lamine, C.; Olsson, G.A.; de Roest, K.; Rogge, E.; Šūmane, S.; Tisenkopfs, T. Rethinking the Links between Farm Modernisation, Rural Development and Resilience in a World of Increasing Demands and Finite Resources; European Commission: Brussels, Belgium, 2014.

20. $\mathrm{Xu}, \mathrm{L}$. Integrated Assessment of Sustainable Agri-Food Production System in Shaanxi Province, China. Ph.D. Dissertation, University of Lethbridge, Lethbridge, AB, Canada, 2017.

21. Castellini, C.; Boggia, A.; Cortina, C.; Dal Bosco, A.; Paolotti, L.; Novelli, E.; Mugnai, C. A Multicriteria Approach for Measuring the Sustainability of Different Poultry Production Systems. J. Clean. Prod. 2012, 37, 192-201. [CrossRef]

22. Yin, R.K. Case Study Methodology. In Case Study Research: Design and Methods, 3rd ed.; Sage: Thousand Oaks, CA, USA, 2003. 
23. Cazorla-Montero, A.; de los Ríos-Carmendo, I.; Díaz-Puente, J.M. La Iniciativa Comunitaria Leader Como Model de Desarrollo Rural: Aplicación a La Región Capital de España. Agrociencia 2005, 39, 697-708.

24. De los Ríos-Carmenado, I.; Díaz-Puente, J.M.; Cadena-Iñiguez, J. La Iniciativa Leader Como Modelo de Desarrollo Rural: Aplicación a Algunos Territorios de México. Agrociencia 2011, 45, 609-624.

25. Friedmann, J. Planning in the Public Domain: Discourse and Praxis. J. Plan. Educ. Res. 1989, 8, 128-130. [CrossRef]

26. Sen, A. The Living Standard. Oxf. Econ. Pap. 1984, 36, 74-90. [CrossRef]

27. Davidson, J.; Lockwood, M. Partnerships as Instruments of Good Regional Governance: Innovation for Sustainability in Tasmania? Reg. Stud. 2008, 42, 641-656. [CrossRef]

28. Grin, J. The Politics of Transition Governance in Dutch Agriculture. Conceptual Understanding and Implications for Transition Management. Int. J. Sustain. Dev. 2012, 15, 72-89. [CrossRef]

29. Heley, J. Soft Spaces, Fuzzy Boundaries and Spatial Governance in Post-Devolution Wales. Int. J. Urban Reg. Res. 2013, 37, 1325-1348. [CrossRef]

30. IPMA. Bases Para La Competencia En Dirección de Proyectos: Versión 3.1.; IPMA: Valencia, Spain, 2010.

31. Hulme, D. Learning and Not Learning from Experience in Rural Project Planning. Public Adm. Dev. 1989, 9, 1-16. [CrossRef]

32. Saldarriaga, M.A.; Structural policies specialist Central Reserve Bank of Peru. email message to authors. 17 May 2013.

33. MINAG. Comercialización de Pollos y Gallinas En Los Centros de Acopio de Lima Metropolitana y Callao; MINAG: Lima, Perú, 2018.

34. INEI. Censo Nacional de Mercados de Abasto; INEI: Lima, Peru, 2016.

35. INEI. Encuesta Demográfica y de Salud Familiar; INEI: Lima, Peru, 2017.

36. Carranza, L. Contexto Nacional e Internacional y el Sector Avícola Peruano. Presented at Semana del Avicultor Conference, Lima, Peru, Junio 2011.

37. Aldrich, H.E.; Staber, U.H. Organizing Business Interests: Patterns of Trade Association Foundings, Transformation, and Deaths. In Ecological Models of Organization; Carrol, G., Ed.; Ballinger: Cambridge, MA, USA, 1988; pp. 111-126.

38. Oliver, C. Determinants of Interorganizational Relationships: Integration and Future Directions. Acad. Manag. Rev. 1990, 15, 241-265. [CrossRef]

39. Hemphill, T.A. Self-Regulating Industry Behavior: Antitrust Limitations and Trade Association Codes of Conduct. J. Bus. Ethics 1992, 11, 915-920. [CrossRef]

40. David, P.; Baron, D.P. The Nonmarket Strategy System. Sloan Manag. Rev. 1995, 37, 73.

41. Hillman, A.J.; Hitt, M.A. Corporate Political Strategy Formulation: A Model of Approach, Participation, and Strategy Decisions. Acad. Manag. Rev. 1999, 24, 825-842. [CrossRef]

42. Barnett, M.L. One Voice, but Whose Voice? Exploring What Drives Trade Association Activity. Bus. Soc. 2013, 52, 213-244. [CrossRef]

43. Williamson, O. Wage Rates as a Barrier to Entry: The Pennington Case in Perspective. Q. J. Econ. 1968, 82, 85-116. [CrossRef]

44. Pelletier, N. Environmental Performance in the US Broiler Poultry Sector: Life Cycle Energy Use and Greenhouse Gas, Ozone Depleting, Acidifying and Eutrophying Emissions. Agric. Syst. 2008, 98, 67-73. [CrossRef]

45. Herrero, M.; Thornton, P.K.; Notenbaert, A.M.; Wood, S.; Msangi, S.; Freeman, H.A.; Bossio, D.; Dixon, J.; Peters, M.; Van De Steeg, J.; et al. Smart Investments in Sustainable Food Production: Revisiting Mixed Crop-Livestock Systems. Science 2010, 327, 822-825. [CrossRef] [PubMed]

(C) 2018 by the authors. Licensee MDPI, Basel, Switzerland. This article is an open access article distributed under the terms and conditions of the Creative Commons Attribution (CC BY) license (http:/ / creativecommons.org/licenses/by/4.0/). 